\title{
12. UNIVERSITAT
}

\author{
WORKING PAPERS
}

\section{Col·lecció "DOCUMENTS DE TREBALL DEL DEPARTAMENT D'ECONOMIA”}

Environmental Regulations in the Hog Farming

Sector: A Comparison of Catalonia, Spain and Manitoba, Canada

Doug Ramsey

Victoria Soldevila

Document de treball $n^{\circ}$ - 27- 2010

\section{DEPARTAMENT D'ECONOMIA}

Facultat de Ciències Econòmiques i Empresarials 


\section{UNIVERSITAT
ROVIRA I VIRGILI}

Edita:

Departament d'Economia

http://www.fcee.urv.es/departaments/economia/public_html/index.html Universitat Rovira i Virgili

Facultat de Ciències Econòmiques i Empresarials

Avgda. de la Universitat, 1

432004 Reus

Tel. +34977 759811

Fax +34977300661

Dirigir comentaris al Departament d'Economia.

Dipòsit Legal: T - 2023 - 2010

ISSN $1988-0812$ 


\title{
Environmental Regulations in the Hog Farming Sector: A Comparison of Catalonia, Spain and Manitoba, Canada
}

\author{
Doug Ramsey \\ Rural Development Institute \\ Brandon University \\ $27018^{\text {th }}$ Street \\ Brandon, Canada \\ Tel. +204 5718514 \\ E-mail: ramsey@brandonu.ca \\ Victoria Soldevila \\ Departament d'Economia \\ Universitat Rovira i Virgili \\ Avgda. Universitat, 1 \\ Reus, Spain \\ Tel. +34 977758909 \\ E-mail: mariavictoria.soldevila@urv.cat
}

\begin{abstract}
This article examines the governance structures for managing the location and operation of Intensive Livestock Farming Operations (ILFOs). The article focuses on the hog sector and compares two very different jurisdictions: the Province of Manitoba, Canada and the Autonomous Community of Catalonia, Spain. Both are regions that have witnessed recent increases in hog production, including increasing spatial concentration of ILFOs and increasing size of those ILFOs. Policy has both fostered and sought to manage the increased production. Following a brief background description of restructuring, the changing legislative framework for Manitoba and Catalonia are described.
\end{abstract}

Keywords: environmental regulations, hog farms, manure management, animal feeding operations

JEL: Q15, Q58, R52, O57 


\section{Introduction}

Agricultural restructuring, including increasing operational scales, pervades much of western agriculture. Some regions face depopulation as farmers sell their land, squeezed out by declining margins. The Great Plains of the United States and the western Prairie regions of Canada are two notable examples (Troughton, 2005). Declining populations put pressure on the ability of communities and regions to offer basic services such as health, education, and retail. Other regions, often those adjacent to urban centres, have a different outcome. Intensive, specialized, industrial agricultural operations often conflict with urban society, including former urban residents who have moved into the adjacent countryside seeking a 'rural life' or tourism activities. Non-farm residents have voiced concerns about the noise, smell, and dust generated from large machinery and animal production in what are now commonly referred to as 'nuisance complaints' (Mann and Kogl, 2003). Issues such as these have resulted in the enactment of "Right-to-Farm" legislation in North America (Bergner and Centner, 1989; McNulty, 2001; Centner, 2002). One aspect of agricultural restructuring has brought conflict to the countryside regardless of whether it is urban adjacent or in a depopulating rural region: the restructuring in animal-based agricultural systems. In particular, we are referring to what have been referred to as Confined Animal Feeding Operations (CAFOs) (Curran, 2002), Concentrated Feeding Animal Operations (also CAFOs) (Centner, 2004; Donham et al., 2007; Ilea, 2009), and Intensive Livestock Operations (ILOs) (Epp and Whitson, 2001; MacLachlan, 2005). Regardless, the key terminology offers insight into the issues: intensive, concentrated and confined. Intensive infers to large numbers of animals raised in a small area. Concentrated refers to intensity but also certain geographic regions where intensive animal operations exist. Confined simply refers to those operations that do not allow free grazing. Such operations include dairy, beef cattle, hogs, and poultry.

This paper is concerned primarily with hogs, although the literature on dairy and beef cattle operations will be referred to. We adopt the term "Intensive Livestock Farming Operations" (ILFOs) as it recognizes intensiveness through concentration and confinement, livestock which recognizes our interest in hogs, and farming operations as the animal raising systems are part of a larger agricultural system and most specifically, the land in which manure is stored in and spread upon. ILFOs are certainly not without controversy. The debate often pits farmers and economic development advocates against those who have environmental concerns (Lawley and Furtan, 2008). Responding to environmental concern has taken several forms. In a recent essay, Ilea (2009), for example, compares issues in North American and Europe with respect ILFOs, including: increased emissions, increased global demand for meat, changing regulatory regimes to address environmental concerns, health and nuisance issues, land degradation, water consumption, and animal ethics. In providing a general overview of the ranges of issues with ILFOs, llea (2009) illustrates the importance of mitigating impacts on the natural environment and on the quality of life of those living in rural areas adjacent to ILFOs. Regardless, increasing demands for products such as pigmeat has been a trend for decades (Bichard and Bruce, 1989) and continues to be. llea (2009), for example, estimates that global livestock production is expected to double by 2050 . 
The purpose of this paper is to provide a comparative analysis of environmental regulations that govern ILFOs in Spain and Canada. Catalonia and Manitoba were chosen for the comparison because both jurisdictions have witnessed great hog production increases over the past decade and both have to face environmental problems coming from hog farms. Further, there are similarities and differences between Catalonia and Manitoba, that could help inform other jurisdictions that are coping with expanding production in livestock sectors. Specific regulatory changes can be identified, including: land use planning and zoning (i.e. ILFO location and size), manure management regulations, odour mitigation, and water protection. Each of these issues is reviewed briefly through the literature. The cases of Catalonia, Spain and Manitoba, Canada are then offered as examples of mitigation policies. The specific foci in the comparative cases are on zoning to limit concentration and regulations affecting ILFO operations, including manure management to address water and odour concerns.

\section{Scholarly Context}

As noted by Wossink and Wefering (2003), areas of livestock concentration have developed in the United States and Europe. The impacts of concentrations in North Carolina were illustrated by Furuseth $(1997,2001)$. Since that time, moratoria have been implemented in a number of jurisdictions, including North Carolina (Furuseth, 2001), Kentucky (Curran, 2002), Quebec (Dessureault and Myles, 2006), and Manitoba (CBC, 2008). In addition to restricting ILFO location, governments can monitor and regulate ILFOs (Huang, Magleby and Somwaru, 2003; Innes, 2000). While some research on the impacts of ILFOs in Canada has been done on the hog sector (Novak, 2003, Qualman, 2001, Ramsey et al., 2005), apart from an examination of the potential for community-based monitoring of hog farms in Manitoba (Moyer et al., 2008), little research exists on the changing legislative frameworks that impact the siting and operational regulations of hog-based ILFOs in Canada.

Research based on regulations in particular jurisdictions has also been done, including for example, Germany (Deunert, Lennartz and Tiemeyer, 2007), Denmark (Bonde, 1994), the Netherlands (Schröder and Neeteson, 2008), Mexico (Espejo, 2006), Taiwan (Yang, Hsiao, and $\mathrm{Yu}, 2008$ ), the United States (Goldstein and Berman, 1995), Catalonia (Soldevila, 2009) and Canada (Troughton, 2005). One of the most common policies relates to manure management, particularly with respect to managing manure as a solid waste and regulating its use as a nutrient source (Meloy, 2002; Schröder and Neeteson, 2008; Soldevila, 2009). While using livestock manure for soil building and fertilizer is not new, given the concentration and industrialization of livestock operations in the past 30 years, management systems have had to be developed to respond to new legislation (e.g. Karmakar, Lague, Agnew, and Landry, 2007). Others, in fact, have found that restructuring to meet new regulations can produce production efficiencies (Yang, Hsiao and Yu, 2008).

Two specific concerns with manure management relate to odour control and protecting water supplies. Mahin (2001) examines odour regulations and guidelines in North America, Europe, Asia, New Zealand and Australia. Their comparative analysis includes a focus on the impacts of 
European "olfactometry standardization." Also related to manure management are regulations to protect water (Centner, 2004; Deunert, Lennartz and Tiemeyer, 2007; Espejo, 2006). In these regulations, the primary concern is leaching of two particular nutrients into the water table: nitrogen and phosphorus (Schröder and Neeteson, 2008). Issues of odour control have been a concern in Manitoba (Novek, 2003), while concerns about contaminating water supplies have been central to legislative responses in Catalonia and Manitoba. These issues are detailed in the comparative case studies.

\section{Hog Farm Trends in Manitoba and Catalonia}

\section{Manitoba}

For more than a decade, Manitoba agriculture has diversified at a greater rate than other Canadian provinces. This is due in part to diversification from wheat, the once dominant prairie grain, to other grains and oilseeds (e.g. canola and flax), but primarily because of farmers expanding their operations to include hog production. The latter is due in large part to the construction of a state-of-the-art hog processing plant in Brandon, Manitoba. This plant (Maple Leaf Meats) has the capacity to process 90,000 hogs per week (Ramsey et al., 2005). The reasons for the plant location and subsequent increased production include a direct role of the state in eliminating the Manitoba Pork Marketing Board and incentives to Maple Leaf Meats to locate in Brandon (Walberg and Ramsey, 2002; Novek, 2003).

Statistics Canada (2010) reported that in January, 2010, Manitoba accounted for $24 \%$ of Canadian hog production, behind the country's two largest populated provinces, Ontario (28\%) and Quebec (37\%). As noted in Table 1, the number of hogs raised in Manitoba has increased from just over 600,000 in 1976 to almost 3 million in 2006. Since this time, production has fallen to 2.5 million (Statistics Canada, 2010) due to issues such as Influenza A virus (H1N1), Bovine spongiform encephalopathy (BSE), Country of Origin Labelling (COOL), all of which resulted in a fall in hog prices. At the same time, between 1976 and 2006, the number of farms reporting commercial hogs fell from 6,069 to 1,188 (Table 1). The differential illustrates the concentration of production on fewer farms from 762 in 1976 to 3,818 in 2006 (Table 1). Further, while in 1976, 91 percent of farms reporting hogs had fewer than 300, compared to $0.1 \%$ who reported more than 4,685 , by 2006 only $36.3 \%$ of farms reported fewer than 273 hogs (Table 2). Similarly, while in 1976, only $3.7 \%$ of hogs in Manitoba were raised on operations greater then 4,685, by 2006 this figure had increased to $73.3 \%$. As an example, of the 23 Census Divisions in Manitoba, Division 2 accounted for most of the Manitoba hog production. In 2001, 968,447 hogs (33\%) were raised on 337 farms (44\%). Five years later, the number of farms reporting hogs had fallen to 267, while production had increased to $1,078,991$ hogs, or $36.8 \%$ of the total in Manitoba (Statistics Canada, 2006). 


\section{Catalonia}

Spain is the second largest hog producer in the EU after Germany. In 2009, Catalonia accounted for $25 \%$ of Spanish hog production (MARM, 2010). Intensive pig production in Catalonia began in the 1960s. The main actors in the rapid progression towards intensive hog operations were feedstuff factories who established contracts with farmers. Under these contracts, feedstuff factories provided piglets, feed and medicine to the farmer, with the farmer receiving payment per animal for their services, machinery and equipment. For Catalan farmers, pig production under contract provided the opportunity to diversify the farm and, in doing so achieve higher economic returns. It was a good way to maintain production on farms of small acreages as the feed was provided by firms that farmers contracted with. In recent years, approximately threequarters of fattening farms work under integration contracts (DAR, 2010) In the 1970s and 1980s, increasing concentration of production activities on the farm was rapid, resulting in higher levels of hog farm specialization (Table $1 \mathrm{a}$ and $1 \mathrm{~b}$ ). Those farms use pig feedstuffs. They don't use their own stuff production..

As noted in Table 3, just over one million hogs were reported in 1970, compared to almost seven million in 2008. Since the 1990s, Catalonia has become an important European hog producing region, primarily for export, now accounting for approximately $70 \%$ of Spanish hog exports. Related to this change, and similar to Manitoba, Catalonia has experienced recent trends toward ILFOs as the mode of raising hogs and with this increases in the scale of production per farm and concentration in the location of farms reporting hogs. Increasing concentration of production activities on the farm was rapid, resulting in higher levels of hog farm specialization (Table 3). Since the 1990s, while hog inventories increased by almost two million, the number of farms reporting hogs fell from 14,000 to 5,000, a decline of $65 \%$ (Table 4). In fact, larger, those reporting more than 1000 hog places, account for more than $50 \%$ of total hogs in Catalonia. Hog production inventories are concentrated in two regions, northcentral (Osona) and western (Noguera, Segrià and Pla d'Urgell) Catalonia.

The value chain from farm to grocery store is quite different in Catalonia than Manitoba (Soldevila, Viladomiu and Francès, 2009). It is much more segmented with small and medium slaghteurhouses and a huge variety of processing plants. About half of the pork production is processed. Catalonia produces a wide variety of pig meat derivatives, e.g popular Serrano ham. There is also great diversity of processed at the local level.

\section{Legislation in Manitoba and Catalonia}

\section{Manitoba}

The expansion of the hog sector in Manitoba, brought about in large part by the opening of the Maple Leaf Meats processing plant in Brandon, Manitoba, in 1999, was soon met by new legislation restricting hog barn location and size. In part, this was based on need, but also because as the new plant began production, a provincial election in Manitoba saw as change in 
government from the Progressive Conservative Party to the New Democratic Party (N.D.P.), a left of centre party. Soon after forming government, the NDP established the Livestock Stewardship Panel that was charged with examining a range of issues related to livestock production in Manitoba. Based on the final report (Tyrchniewicz et al., 2000), several legislative actions have taken place, including the establishment of the Livestock Manure and Mortalities Management Regulation (2004), the Water Protection Act (2006), and major revisions to The Planning Act (2006). The latter included seven new sections specific to livestock operations: zoning by-laws, minimum location and setback requirements, standard review process for larger livestock operations, notice requirements, clarified provincial and local responsibilities, changes to Technical Review Committees, and the implementation of transitional development approval for livestock operations (Manitoba Conservation, 2006).

At the same time, the Technical Review Panel that approves (or not) livestock operations in Manitoba was modified from examining all proposals of more than 400 animal units to all those more than 300 animal units. At the same time, the NDP offered financial assistance to rural municipalities to develop formal planning districts. Rural Manitoba, then and now, has a complicated array of decision-making approval processes that fall under four general types: rural municipalities that operate with no by-laws, but rather deal with proposals on an individual basis; rural municipalities that operate with by-laws that govern their decisionmaking; rural municipalities that have collectively formed into planning districts but that have not yet received final land use planning approval authority by the provincial government, and; rural municipalities that have collectively formed into planning districts and have obtained final land use planning approval authority by the provincial government (Ramsey et al., 2005).

The second major initiative of the provincial government relates to moratoria on new hog barn construction and expansion of existing operations. First, a province-wide moratorium was established in the fall of 2006. This ban was in place while Clean Environment Commission Hearings were held. Base on that report, in March 2008, a ban was enacted in three zones classified as "intensively developed areas". As shown in Figure 3, these zones are the Red River Special Management Zone (prone to flooding), Southeastern Manitoba (most intensively developed region of Manitoba), and the Interlake (concern over effluent entering the lakes). In addition, new restrictions were established in areas outside of the moratorium regions. The objectives of these guidelines are to provide:

- local governments with a basis for evaluating livestock operations

- assist livestock producers in their efforts to optimize the use of manure, prevent pollution and minimize odour

- a standard which may be used by the Farm Practices Protection Board in determining normal farming practices

- information to the general public

- information for government officials who evaluate livestock operations about potential effects on the surrounding area.

In obtaining approval for an ILFO, one obtains "Conditional Use". The process includes: Application for conditional use (application to minister), preparation of the Technical Review 
Report, setting and holding of public hearing, decision of Council, notice of Decision. There is no appeal process and no development can take place until all local and provincial approvals are received. The most detailed step is the development of the Technical Review Committee's report which includes six criteria: 1) Information provided by proponent; 2) Background information (e.g. soils, geology, hydrology, well reports); 3) Zoning and land use policies; 4) Farm Practices Guidelines; 5) Environmental regulations, and; 6) Other provincial regulations. These criteria are applied to manure handling and storage, application of manure to land, odour control, site selection, and mortality disposal.

Once an ILFO application has been approved, operators must complete a manure management plan. This plan includes operator information, animal unit inventory, manure storage systems information, information on land application, and a field application summary. As outlined by Moyer et al. $(2008,652)$, farmers "are required to obtain four permits and approvals and ... comply with eleven legislative acts" (Table 5).

\section{Catalonia}

Unlike Manitoba, where the provincial government plays the key role in regulating ILFOS and municipalities can decide whether or not to allow ILFOs to be developed, in Catalonia there are four levels of government that regulate the development and operation of ILFOs. These include: the EU government (Nitrates Directive, IPPC Directive, NEC Directive) , the Spanish government (e.g.RD 324/2000, RD 509/2007), the Catalonian government (regulation of manure management plans and Vulnerable Zone prescriptions; reinforcing Spanish government rules), and municipalities (responsible for site licensing) (Table 6). Having said this, environmental regulations in Spain have been developed primarily because of the EU Directives. The main European Environmental Directives affecting hog farming are Council Directive 91/676/EEC concerning the protection of waters against pollution caused by nitrates from agricultural sources (or Nitrates Directive) and Council Directive 96/61/EC of 24 September 1996 concerning integrated pollution prevention and control (or IPPC Directive). Further, Directive 2001/81/EC of the European Parliament and of the Council of 23 October 2001 on National Emissions Ceilings for certain atmospheric pollutants (or NEC Directive) affects the level of gas emissions allowed from hog farms, including spreading manure.

The Nitrates Directive aims to limit to nitrate concentration in waters and lands. This Directive defines "nitrate vulnerable zones" (NVZs) as areas of agricultural land with significant contribution to nitrate pollution at watershed land. A level of 50 milligrams per litre of nitrates in water has been established under this directive. The Directive requires Member States to designate the NVZ in their territory and establish a mandatory Action Programme of measures to reduce nitrate concentration in these areas. The general recommendation is that manure cannot be spread if it will exceed the $170 \mathrm{~kg} / \mathrm{N} / \mathrm{h}$ a allowed in the NVZ. In addition, the Directive requires Member States to establish a voluntary code of good agricultural practice to be followed by all farmers throughout the country. 
In Spain, water pollution by nitrates is mainly due to over-fertilization coming from both agriculture intensive practises and by over-spreading hog manure in land. Traditionally, hog manure and slurry was managed by spreading it on the land as fertilizer. Manure and slurry were also dumped into fluvial systems, however these actions are forbidden by Royal Decree $846 / 1986$.

The Royal Decree 261/1996, of 16 February, on water protection against pollution induced by nitrates from agricultural sources transferred Nitrates Directive into national legislation. In Spain, responsibility for environmental policy has been transferred to regional (Autonomous Communities) government, although central (Spanish State) government retains responsibility over water quality. As the administrative responsibility for the implementation of the Nitrates Directive was becoming unclear, responsibility for implementing it was delegated to regional government (Izcara, 1998). That is, the Royal Decree 261/1996 was delegated to Autonomous Communities to identify NVZs and to create the Code of good agricultural practice and the Action Programme for these vulnerable zones.

The first delimitation of Vulnerable Zones in Catalonia was done by Decree 283/1998 of 21 October on the designation of vulnerable areas with regard to pollution by nitrates from agricultural sources. Last one is in 2009 by AG 128/2009. Between 1998 and 2009 surface with nitrates pollution in Catalonia almost tripled from $11.8 \%$ in 1998 to $34.0 \%$ in 2009. During the same period, the number of municipalities included in the Vulnerable Zones doubled from 203 municipalities in 1998 to 421 in 2009. The "Code of good agricultural practice" is published by the Order of 22 October 1998 and modified by Decree 136/2009. The Code contains recommendations relating to land application of fertilizers (including manure) and manure and dugs storage. The Code recommendations are optional for farmers in general but compulsory for farming in vulnerable zones.

Finally, Decree 205/2000 established the "Action Programme applicable in zones vulnerable to pollution by nitrates from agricultural sources". The main objective of this programme was to ensure that nitrogen disposal coming from livestock (organic fertilizer) did not exceed 210 kilograms of nitrogen per hectare per year. More recently, Decree 136/2009 established the nitrogen level at $170 \mathrm{~kg} \mathrm{~N} / \mathrm{ha} / \mathrm{year}$, in accordance with EU recommendations. For each "area" declared a "vulnerable zone", the Action Programme contains compulsory rules relating to periods when the land application of fertilizer is prohibited and the limitation of the land application of fertilizers based on a balance between the foreseeable nitrogen requirements depending of crops type and land type (dry/irrigated).

Manure Management has become a crucial point in meeting the Nitrate Directive in Catalonia. The Manure Management Plan in Catalonia is similar to that of Manitoba. The application requires farm operator data (e.g. farm size - area and animal units), approval from an agronomist about the farm, manure and nitrogen calculations (including for storage), paper work for contracting to waste management firms, a description of the land if manure is to be discharged on farm, and a transportation plan if the manure discharge land is 15 kilometres or greater from an ILFO. The fertilizing plan requires hog producers lacking enough land to identify 
appropriate solutions. Different instruments were implemented at collective (e.g. cogeneration plants and compost plants) and individual (mechanical separator, physiochemical systems, and biological systems) levels. Also different collective plans are implemented in order to reduce slurry transport costs. Important to note is that is that manure management has resulted in reduced intensification (as use of mineral fertilization) in farms without livestock in Catalonia. That is, service company and hog farmer's payments to crop farmers have convinced crop farmers to use manure and slurry to fertilize their land.

The Nitrate Directive imposes greater regulations and restrictions upon farm enlargement (or the creation of new ones) in Vulnerable Areas. New farms in Catalonia are located outside Vulnerable Areas and outside the high density areas. Nevertheless, in view of the regional results of the study coming from MARM (2008), we can conclude that a negative evolution of the quality of subterranean water inside the vulnerable zones declared as such in 1998 has been observed. The percentage of stations within the zones declared vulnerable in 1998 that have experienced an increase in their nitrate concentration is $56.4 \%$, compared to the $35.3 \%$ that have seen a reduction.

National and Regional governments are trying to promote technical solutions to environmental problems in hog production. Regional governments have promoted the use of phytasa in feedstuff and multiphase feeding (ASAF programme). Also at regional level there is a new institution, GESFER, to help farmers in manure management. Financial support is also provided to build manure facilities as cogeneration plants. Further, air quality and emissions of greenhouse gases, due to the NEC Directive, are now supported through the "Plan de Biodigestion de purines", recently approved (AAR/386/2009). Lastly, the number of applications to build a biodigestor plant is very high, particularly in Catalonia.

ILFOS are also specifically affected by IPPC Directive as it is applied large hog and poultry farms. According with Royal Decree 509/2007 which translates IPPC Directive into National regulations, farms affected by the IPPC Directive are intensive farms with more than:

- 2000 places for fattening hogs (more than $30 \mathrm{kgs}$ ),

- 2500 places for fattening hogs (more than $20 \mathrm{~kg}$ ),

- 750 places for sows,

- 530 places sows (rearing and fattening).

Twenty-eight percent of farms affected by IPPC Directive in Spain are located in Catalonia. These farms are required to report information on atmospheric emissions, water and soil contamination and manure treatments. Farms must have an Environmental Integrated Authorization (EIA) which must be renewed every eight years. They must use the recommended technologies by industry BREF ('best available technologies- BAT').

Regional Government are also required to administer ILFOs regulations with Law 3/98 of 27 February on the Integral Intervention of the Environmental Administration and recently with Law 20/2009 of environmental and prevention control of activities. The administrative proceedings established for Law 20/2009 and forthcoming degrees and laws are based on a particular farm classification (Table 7). For farms "Annex I.1" it compulsory to have an 
"environmental authorization". The authorization comes from the Housing and Environmental Department (DMAH) of Regional Government. Farms in "Annex II" are required to obtain an "Environmental License". The license is granted by City Councils. Farms in Annex III are subject to a "Communication regime" which also comes from City Councils. The Law 20/2009 requires farmers to provide the Manure Management Plan according to "Action Programs for Vulnerable Zones" for all pig farms. For the moment, the effect of IPPC regulations and Regional regulations on ILFOs is that the strict requirements discourage farm enlargement if they are close to a classification limit. However, it has not completely halted the tendency to increasing farm sizes.

Municipalities influence hog farms in three ways: farm location, environmental regulations, and administrative interventions by local government. Affecting farm location, Municipal Ordination Planning ("Pla d'Ordenacio Urbanistica Municipal"- POUM) regulates uses of nonurbanizable land (among uses allowed by Laws). That is, City council can, quite discretionally, forbid new farms in the municipality, but that must be strongly justified in the POUM by an Environmental evaluation. On the other hand, City councils can endure environmental legislation in their municipality. With respect to hog farms, municipalities may set stricter limitations in manure spreading. Municipalities can also restrict activities based on odour control, including requiring farmers to develop additional efforts to control odours coming from farm or manure storage. In fact, foul smell is the element that generates most social conflicts at the local level (Viladomiu, reference). Several conflicts have been detected in rural areas where tourism is promoted. Regulations enacted include forbidding the spreading of manure or slurry during the weekend. Also in some cases anaerobic tanks were introduced. Regional government is currently preparing a regulation about odours that could have an impact on fattening operations.

\section{Summary and Conclusions}

Hog farming in Catalonia and Manitoba are intensive models fostered by industry (slaughterhouses in Manitoba case, and feed factories in Catalonia case), who profited from farm crisis to impose intensive models of productions. As competitive pressures increasing, farmers tend to profit scale economies by increasing of size farms. At the end, the model has to face, in both cases, with environmental concerns and conflicts in rural areas (with newcomers in rural Manitoba and with tourism activities in rural Catalonia).

Other similarities exist between Manitoba and Catalonia, including: increasing hog production (scale and volume and more integration with processing), a decline in number of hog farms countered by an increase in concentration of production, and new legislation on manure management, including storage and spreading. In both, there have been recent processes to ban further ILFO development in specific jurisdictions that have either been identified as overdeveloped and/or are regions with potential environmental implications (e.g. water tables). 
Differences can also be identified. In Catalonia, the EU and national levels of control with respect to regulating and monitoring ILFOs, as yet there are no formal moratoria (total or regional), and manure can be managed off farm through contracts with other farmers and/or waste management firms. In Manitoba, the provincial government holds most of the power over decision-making, particularly through the establishment of moratoria while municipalities have the ultimate power to decide whether or not a proposal can move forward when outside of any moratoria zones. Further, in Manitoba, manure must be managed on the farm in which it is produced.

Different levels of Government have supposed some delays and confusions in regulations in Catalonia. Nevertheless the fact than some regulations are prescriptions coming from EU, results in environmental policies affecting ILFOs are not really affected by changes in Regional or Local Government. In Manitoba case, environmental policies affecting ILFOs can be more affected by political cycle.

In sum, it seems than former environmental regulations have not been able to reduce pollution concerns neither reduce pig inventories. Environmental regulations only have moved the problem to other areas but it haven't made a difference in the way of raising pigs. Environmental regulations seem not capable of twist the tendency to big farms and increasing inventories.

\section{References}

Bergner, J.C., Centner, T.J., 1989. Agricultural nuisances and right-to-farm laws: implications of changing liability rules. Review of Regional Studies. 19(1): 23-30.

Bichard, M., Bruce, E.A., 2008. Pigmeat production worldwide. Outlook on Agriculture. 18, 145151.

Bonde, T.A., 1994. Current Danish policies to abate nutrient emissions from agriculture. Marine Pollution Bulletin. 29, 450-454.

Centner, T.G., 2002. Agricultural nuisances qualifying legislative "right-to-farm" protection through qualifying management practices. Land Use Policy. 19, 259-267

Centner, T.G., 2004. New regulations to minimize water impairment from animals rely on management practices. Environment International. 30, 539-545.

Centner, T.G., Wetzstein, M.E., Mullen, J.D., 2008. Small livestock producers with diffuse water pollutants: adopting a disincentive for unacceptable manure application practices. Desalinisation. 226, 66-71.

Curran, M., 2002. Local environmental security and industrial hog farming in Kentucky. Regional Development Dialogue. 23, 54-68. 
Dessureault, D. Myles, G., 2006. Canada - Agricultural Situation. This Wek in Canadian Agriculture. Gain Report Number CA6058. 32, 1-4.

http://ottawa.usembassy.gov/content/embconsul/pdfs/fas twica32_2006.pdf Site visited, November 23, 2010.

Deunert, F., Lennartz, B., Tiemeyer, B., 2007. Legislative effects on the development of surface water quality in rural areas in Northern Germany. Journal of Cleaner Production. 15, 1507-1513.

Donham, K.J., Wing, S., Osterberg, D., Flora, J.L., Hodne, C., Thus, K.M. and Thorne, P.S. 2007. Community health and socioeconomic issues surrounding concentrated animal feeding operations. Environmental Health Perspectives. 115(2):317-320.

Durrenberger, P., Thu, K.M., 1996. Eh expansion of large scale hog farming in lowa: the applicability of Goldschmidt's findings fifty years later. Human Organization. 55, 409415.

Epp, R., Whitson, D., 2001. Introduction: writing off rural communities. In Epp, R. and D. Whitson (eds.) Writing Off the Rural West: Globalization, Governments and the Transformation of Rural Communities. Edmonton: University of Alberta Press. (xiii-xxxv).

Espejo, R.P., 2006. Costs of the wastewater standard in pig production in Mexico. Environment, Development and Sustainability. 8, 391-411.

Furuseth, O., 2001. Hog farming in Eastern North Carolina. Southeastern Geographer. 41(1), 5364.

Furuseth, O., 1997. Restructuring of hog farming in North Carolina: explosion and implosion. Professional Geographer. 49, 391-403.

Goldstein, A.L., Berman, W., 1995. Phosphorus management on confinement dairies in southern Florida. Ecological Engineering. 5, 357-370.

Huang, W.Y., Magleby, R., Somwaru, A., 2003. The economic impacts of alternative manure management regulations on hog farms in the heartland: An individual-farm analysis. Journal of Sustainable Agriculture. 22, 39-59.

Ilea, R.C., 2009. Intensive livestock farming: Global trends, increased environmental concerns, and ethical solutions. Journal of Agricultural and Environmental Ethics. 22, 153-167.

Innes, R., 2000. The economics of livestock waste and its regulation. American Journal of Agricultural Economics. 82, 97-117. 
Karmakar, S. Lague, C., Agnew, J., Landry, H., 2007. Integrated decision support system (DDS) for manure management: A review and perspective. Computer and Electronics in Agriculture. 57, 190-201.

Lawley, C. Furtan, H., 2008. The political trade-off between environmental stringency and economic development in rural America. Journal of Regional Science. 48, 547-566.

MacLachlin, I., 2005. Feedlot growth in southern Alberta: a new-Fordist interpretation. . In: Essex, S.J., Gilg, A.W., Yarwood, R.B. (eds.), Rural Change and Sustainability: Agriculture, the Environment and Communities. CABI, Wallingford, pp. 28-47.

Mahin, T.D., 2001. Comparison of different approaches use to regulate odours around the world. Water Science and Technology. 44, 87-102.

McNulty, T.B., 2001. The Pennsylvanian farmer receives no real protection from the Pennsylvania Right to Farm Act. Penn State Environmental Law Review. 10(1): 81-104.

Manitoba Conservation. 2006. An Examination of the Environmental Sustainability of the Hog Industry in Manitoba. Government of Manitoba, Winnipeg.

Mann, S. , Kogl,H., 2003. On the acceptance of animal production in rural communities. Land Use Policy. 20, 243-252

Meloy, M.M., 2002. An overview of nutrient management requirements in Pennsylvania. Penn State Environmental Law Review. 10, 249-294.

Moyer, J., Fitzpatrick, P., Diduck, A., Froese, B., 2008. Towards community-based monitoring in Manitoba's hog industry. Canadian Public Administration. 51, 637-658.

Novek, J. 2003. Intensive hog farming in Manitoba: transnational treadmills and local conflicts. Canadian Review of Sociology and Anthropology. 40, 3-26.

Ramsey, D., 2004. Lack of Development in the Regulation of Intensive Livestock Production in Manitoba. In Ramsey, D. and C. Bryant (eds.) The Structure and Dynamics of Rural Territories. Rural Development Institute, Brandon University. 272-286.

Ramsey, D., Everitt, J., 2001. Post-Crow Farming in Manitoba: An Analysis of the Wheat and Hog Sectors. In: Epp, R., Whitson, D. (Eds.) Writing off the Rural West: Globalization, Governments, and the Transformation of Rural Life. University of Alberta Press, Edmonton. pp. 3-20.

Ramsey, D., Everitt, J., Behm, L., 2005. People and Hogs: Agricultural Restructuring and the Contested Countryside in Agro- Manitoba. In: Essex, S.J., Gilg, A.W., Yarwood, R.B. 
(eds.), Rural Change and Sustainability: Agriculture, the Environment and Communities. CABI, Wallingford, pp. 48-67.

Rowe, H.I., Bartlett, E.T., Swanson, L.E. Jr., 2001. Ranching motivations in 2 Colorado counties. Journal of Range Management. 54, 314-321.

Schröder, J.J., Neeteson, J.J., 2008. Nutrient management regulations in The Netherlands. Geoderma. 144, 418-425.

Schwabb, J., 1998. Planning and zoning concentrated animal feeding operations. APA Planning Advisory Service Reports. 482, 1-72.

Soldevila, V., Viladomiu, L., Francès, G., 2009. Catalonian Pork Value Chain's Resilience : ready for environmental challenge? Paper Presented to the $113^{\text {th }}$ EAAE Seminar "A resilient European food industry and food chain in a challenging world", Chania, Crete, Greece. http://ageconsearch.umn.edu/bitstream/58134/2/Soldevila.pdf Site visited November 24, 2010.

Soldevila, V. ,2009. Les repercusions de la Directiva Nitrats sobre la filiere porcina a Catalunya. Monografies 1. DAR.

Troughton, M.J., 2005. Fordism rampant: the model and reality, as applied to production, processing and distribution in the North American agro-food system. In: Essex, S.J., Gilg, A.W., Yarwood, R.B. (eds.), Rural Change and Sustainability: Agriculture, the Environment and Communities. CABI, Wallingford, pp. 13-27.

Tyrchniewicz, E., Carter, N., Whitaker, J., 2000. Sustainable Livestock Development in Manitoba: Finding Common Ground. Report prepared for the Government of Manitoba. Winnipeg. http://manitobapork.com/uploads/livestock.pdf Site Visited November 23, 2010.

Walberg, B., Ramsey, D., 2002. Approving Intensive Livestock Operations (ILOs): Conflict in the Countryside in Southwestern Manitoba. Prairie Perspectives. 5:270-292.

Wossink, A., Wefering, F., 2003. Hot spots in animal agriculture, emerging federal environmental policies and the potential for efficiency and innovation offsets. International Journal of Agricultural Resources, Governance and Ecology. 2, 228-242.

Yang, C.C., Hsiao, C.K., Yu, M.M., 2008. Technical efficiency and impact of environmental regulations in farrow-to-finish swine production in Taiwan. Agricultural Economics. 39, 51-61. 


\begin{tabular}{|c|c|c|c|c|}
\hline Year & $\begin{array}{l}\text { \# Farms } \\
\text { reporting } \\
\text { Hogs }\end{array}$ & $\begin{array}{l}\text { \# Farms } \\
\text { reporting gross } \\
\text { receipts of } \\
\$ 2,500 \text { or more }\end{array}$ & Number of Hogs* & $\begin{array}{l}\text { Hogs Slaughtered } \\
\text { in Manitoba** }\end{array}$ \\
\hline 1976 & 6,069 & 821 & $625,934 \quad(762)$ & 795,580 \\
\hline 1981 & 5,098 & 1,011 & $874,995 \quad(865)$ & $1,146,014$ \\
\hline 1986 & 3,563 & 1,111 & $1,071,195$ & $1,637,686$ \\
\hline 1991 & 2,969 & 1,242 & $1,287,196(1,036)$ & $1,967,649$ \\
\hline 1996 & 2,064 & 649 & $1,777,352(2,739)$ & $1,938,028$ \\
\hline 2001 & 1,668 & 968 & $2,540,220(2,624)$ & $4,147,548$ \\
\hline 2006 & 1,188 & 768 & $2,932,548(3,818)$ & $4,273,282$ \\
\hline \multicolumn{5}{|c|}{$\begin{array}{l}*()=\text { average number of hogs per farm } \\
* * \text { includes hogs from other provinces }\end{array}$} \\
\hline \multicolumn{5}{|c|}{$\begin{array}{l}\text { Source: Statistics Canada, Manitoba Ministry of Agriculture, Food and Rural } \\
\text { Initiatives (2006) }\end{array}$} \\
\hline
\end{tabular}


Table 2. Percentage Distribution of Hog Farms by Farms Reporting and Number of Animals

\begin{tabular}{|c|c|c|c|c|}
\hline & 1976 & 1986 & 1996 & 2006 \\
\hline \multicolumn{5}{|c|}{$\begin{array}{l}\text { \% Distribution of farms by size class - } \\
\text { Number of Farms Reporting }\end{array}$} \\
\hline $\begin{array}{l}1-272 \text { pigs } \\
273-1,127 \\
1,128-4,684 \\
4,685+\end{array}$ & $\begin{array}{l}91.4 \\
7.4 \\
1.2 \\
0.1\end{array}$ & $\begin{array}{l}73.7 \\
21.7 \\
3.8 \\
0.8\end{array}$ & $\begin{array}{l}51.7 \\
31.7 \\
11.5 \\
5.2\end{array}$ & $\begin{array}{l}36.3 \\
25.5 \\
20.4 \\
17.8\end{array}$ \\
\hline \multicolumn{5}{|c|}{$\begin{array}{l}\text { \% Distribution of animals by size class - } \\
\text { Number of Animals }\end{array}$} \\
\hline $\begin{array}{l}1-272 \text { pigs } \\
273-1,127 \\
1,128-4,684 \\
4,685+\end{array}$ & $\begin{array}{l}34.3 \\
34.1 \\
28.0 \\
3.7\end{array}$ & $\begin{array}{l}15.3 \\
38.3 \\
31.1 \\
15.3\end{array}$ & $\begin{array}{l}4.8 \\
20.5 \\
29.1 \\
45.6\end{array}$ & $\begin{array}{l}0.8 \\
6.5 \\
19.3 \\
73.3\end{array}$ \\
\hline
\end{tabular}

Source: Statistics Canada, Census of Agriculture 


\begin{tabular}{|lrr|}
\hline \multicolumn{3}{|c|}{ Table 3. Hog Data Catalonia } \\
\hline Year & Hogs & \multicolumn{2}{|c|}{ Slaughtered hogs } \\
\hline 1976 & 2217276 & 2784931 \\
1981 & 2776962 & 4865909 \\
1986 & 3890810 & 5862015 \\
1996 & 5356192 & 10527993 \\
2001 & 6108609 & 12046325 \\
2006 & 5855717 & 15311693 \\
2008 & 6648283 & 16729435 \\
\hline Source: Anuario Estadistico, many years (MARM) \\
and DAR & \\
\hline
\end{tabular}

\begin{tabular}{|lrr|}
\hline \multicolumn{3}{|l|}{ Table 4. Hog Farm Data Catalonia } \\
\hline Year & Farms reporting hogs & Specialized hog farms (2) \\
\hline 1989 & 14142 & 2420 \\
1999 & 7965 & 3238 \\
2003 & 6426 & 3359 \\
2007 & 5129 & 3230 \\
Source: Census 1989 and 1999, Farm Structure Survey 2003 and 2007 \\
(2) The usual way to analyse farm specialization EU is to calculate \\
the contribution of the different productions to the standard gross margin of the farm. \\
If one production represents more than the 2/3 of the total SGM, \\
then the farm is said to be specialized in this production \\
\hline
\end{tabular}




\begin{tabular}{|l|l|}
\hline Table 5. Legislation Relevant to the Hog Farming Sector in Manitoba \\
\hline $\begin{array}{l}\text { Manitoba Statutes and Regulations } \\
\text { Pertaining to Hog Operations }\end{array}$ & $\begin{array}{l}\text { Manitoba Statutes Containing Express } \\
\text { Authority for Monitoring Functions }\end{array}$ \\
\hline The Animal Diseases Act & The Department of Agriculture, Food and \\
The Contaminated Sites Remediation Act & Rural Initiatives Act \\
The Farmlands Ownership Regulation The & The Agri-Food and Rural Development Council \\
Farm Practices Protection Act & Act \\
The Ground Water and Water Well Act & The Animal Care Act \\
The Planning Act & The Animal Diseases Act \\
The Public Health Act & The Contaminated Sites Remediation Act \\
The Water Protection Act & The Dangerous Goods Handling and \\
The Water Resources Conservation Act The & Transportation Act \\
Water Rights Act & The Environment Act \\
& The Farm Practices Protection Act \\
& The Ground Water and Well Water Act \\
& The Planning Act \\
& The Public Health Act \\
\hline & The Water Rights Act \\
& The Water Protection Act \\
\hline Note: All statutes are contained in the Continuing Consolidation of the Statutes of Manitoba \\
(C.C.S.M.).
\end{tabular}




\begin{tabular}{|c|c|c|}
\hline & $\begin{array}{l}\text { Affecting manure } \\
\text { management }\end{array}$ & Affecting ILFOs \\
\hline EU Regulations & Council Directive 91/676/EEC & $\begin{array}{l}\text { Directive 85/377/EEC } \\
\text { Directive 96/61/EEC } \\
\text { Directive 97/11/EC } \\
\text { Directive 2001/81/EC } \\
\text { Directive 2003/4/EC } \\
\text { Directive 2008/1/EC }\end{array}$ \\
\hline Spain Regulations & $\begin{array}{l}\text { Royal Decree 261/1996 } \\
\text { Royal Decree 324/2000 } \\
\text { Royal Decree 509/2007 }\end{array}$ & $\begin{array}{l}\text { Royal Decree } 2414 / 1961 \\
\text { Royal Decree } 1302 / 1986 \\
\text { Royal Decree } 1131 / 1988 \\
\text { Royal Decree 324/2000 } \\
\text { Royal Decree 3483/ } 2000 \\
\text { Royal Decree } 1073 / 2002 \\
\text { Royal Decree } 1323 / 2002 \\
\text { Law } 16 / 2002 \\
\text { Law } 27 / 2006 \\
\text { Law } 34 / 2007 \\
\text { Royal Decree 509/2007 } \\
\text { Royal Decree } 1 / 2008\end{array}$ \\
\hline Catalonia Regulations & $\begin{array}{l}\text { Decree } 283 / 1998 \\
\text { Decree } 476 / 2004 \\
\text { AG } 128 / 2009 \\
\text { Order of } 22 \text { th October } 1998 \\
\text { Decree } 50 / 2005 \\
\text { Decree } 220 / 2001 \\
\text { Decree } 136 / 2009\end{array}$ & $\begin{array}{l}\text { Order of } 7^{\text {th }} \text { April } 1994 \\
\text { Law } 3 / 98 \\
\text { Decree } 136 / 1999 \\
\text { Law } 1 / 1999 \\
\text { Law } 13 / 2001 \\
\text { Decree } 143 / 2003 \\
\text { Law } 4 / 2004 \\
\text { Decree } 50 / 2005 \\
\text { Law } 20 / 2009\end{array}$ \\
\hline Municipalites Regulations & $\begin{array}{l}\text { Local by-laws (allowed to } \\
\text { increase restrictions to } \\
\text { spreading manure) }\end{array}$ & Local by-laws \\
\hline
\end{tabular}




\begin{tabular}{|c|c|c|c|}
\hline & Annex I.1 & Annex II & Annex III \\
\hline $\begin{array}{l}\text { Farm type (depending on } \\
\text { capacity) }\end{array}$ & $\begin{array}{l}>2.000 \text { finishing pigs } \\
\text { than more } 30 \mathrm{kgs} . \\
>2500 \text { finishing pigs } \\
\text { than more } 20 \mathrm{kgs} \text {. } \\
>750 \text { sows } \\
>530 \text { sows in rearing } \\
\text { to finishing farms }\end{array}$ & $\begin{array}{l}>200 \text { and }<=2000 \\
\text { finishing pigs than } \\
\text { more } 30 \mathrm{kgs} \\
>200 \text { and }<=2500 \\
\text { finishing pigs than } \\
\text { more } 20 \mathrm{kgs} \\
>50 \text { and }<=750 \\
\text { sows } \\
>50 \text { and }<=530 \\
\text { sows in rearing to } \\
\text { finishing farms }\end{array}$ & $\begin{array}{l}>10 \text { and }<=200 \\
\text { finishing pigs } \\
\text { than more } 30 \mathrm{kgs} \\
>10 \text { and }<=200 \\
\text { finishing pigs } \\
\text { than more } 20 \mathrm{kgs} \\
>5 \text { and }<=50 \\
\text { sows } \\
>5 \text { and }<=50 \\
\text { sows in rearing to } \\
\text { finishing farms }\end{array}$ \\
\hline Administrative proceedings & $\begin{array}{l}\text { Environmental } \\
\text { Authorization }\end{array}$ & $\begin{array}{l}\text { Environmental } \\
\text { License }\end{array}$ & $\begin{array}{l}\text { Communication } \\
\text { regime }\end{array}$ \\
\hline $\begin{array}{l}\text { Entity who takes the } \\
\text { decision }\end{array}$ & DMAH & City council & City council \\
\hline
\end{tabular}


